DOI: http://doi.org/10.21698/simi.2018.fp05

\title{
INQUIRY INTO THE POTENTIAL USE OF IONIC LIQUIDS INSTEAD OF INORGANIC ACIDS IN HYDROTHERMAL HYDROLYSIS OF MACROALGAE
}

\author{
Konstantza Tonova, Madlena Lazarova
}

Institute of Chemical Engineering - Bulgarian Academy of Sciences, Acad. G. Bonchev Str., Bldg. 103, 1113-Sofia, konstantzatonova@yahoo.com, Bulgaria

\begin{abstract}
Macroalgae represent a worldwide spread renewable source of valuable biopolymers, polysaccharides and proteins that after pretreatment constitute an intermediate platform for microbial and chemical production. In the present study the potential of some ionic liquids (ILs) to extract and hydrolyze the algal carbohydrates derived from Ulva sp. is examined and compared to the conventional inorganic acid catalysts, $\mathrm{H}_{2} \mathrm{SO}_{4}$ and $\mathrm{HCl}$. The experimental results reveal that the IL, 1-butyl-3-methylimidazolium acetate, is superior to both acid auxiliaries in extracting carbohydrates. The capacity of this IL for splitting reducing sugars under the conditions of hydrothermal hydrolysis is comparable with the power of $\mathrm{HCl}$, but higher than $\mathrm{HCl}$ in terms of monosugar fraction and protein released. The highest yields of reducing and monosugars and of protein are obtained by using the strong dibasic acid, $\mathrm{H}_{2} \mathrm{SO}_{4}$. It could, however, produce dehydration by-products which would incur inhibition of enzymatic and microbial processes fed by the algal liquor.
\end{abstract}

Keywords: alga, carbohydrate, hydrothermal hydrolysis, ionic liquid, Ulva sp.

\section{Introduction}

Ionic liquids (ILs) are molten salts assembled only by ions, usually a chargestabilized organic cation and an inorganic or organic anion. ILs display physical properties unusual for common one-component molecular solvents, such as negligible vapor pressure and high thermal stability. The chemical reactivity towards the plant cellulose matrix, by stoihiometric $\mathrm{H}$-bonding interactions between the cellulose and the IL's ions (Dong \& Zhang 2012, Bogdanov \& Svinyarov 2013), makes the ILs exceptional solvents for cellulose dissolution. However, the effects of the ILs on the plant material pretreatment aimed at biopolymers' degradation have been barely investigated so far.

The present study is a research for potential ILs that could simultaneously enhance the extraction and catalyze the hydrolysis of natural biopolymers (polysaccharides and proteins) so that valuable platform chemicals (simple sugars and amino acids) to be derived from renewable biomass feedstocks. The subject of the study is a widespread marine green macroalgal species, Enteromorpha linza (Guiry 2018). Previously Park and Jeong 2013 studied the hydrothermal hydrolysis of Saccharina japonica alga by ILs as catalysts. It was found that the hydrophilic ILs with acidic anions, $\left[\mathrm{BF}_{4}\right]^{-}$or $\left[\mathrm{HSO}_{4}\right]^{-}$, are able to split the polysaccharide chain and produce reducing sugars to the same extent as the inorganic acid catalyst, $\mathrm{H}_{2} \mathrm{SO}_{4}$. The $\left[\mathrm{BF}_{4}\right]^{-}$ 


\section{INTERNATIONAL SYMPOSIUM "THE ENVIRONMENT AND THE INDUSTRY", SIMI 2018, PROCEEDINGS BOOK}

anion, however, is prone to undergo hydrolysis (Freire et al 2010) and not the IL itself but the released hydrofluoridric acid is mostly responsible for the catalytic action. Acidic conditions were also recommended for the extraction of the main polysaccharide of the green algal species, ulvan (Robic et al 2009, Yaich et al 2014). The ILs based on acetate anion have been recently proved effective in pre-treating lignocellulosic material prior to enzymatic conversion to monosugars (Raj et al 2018, Husson et al 2018). In these studies the plant material has been immersed and incubated in pure ILs. Here, minimizing the IL's amount, we use dilute solutions for hydrothermal hydrolysis of Ulva alga biomass. It has been recently reported that the Ulva sp. has the highest potential for economic income among the photosynthetic organisms, including macroalgae, microalgae and terrestrial plants, based on the prices of extractable and purified monosaccharides (Robin et al 2018 a, b).

\section{Materials and Methods}

1-Butyl-3-methylimidazolium acetate, [ $\left.\mathrm{C}_{4} \mathrm{C}_{1} \mathrm{im}\right] \mathrm{Ac}$, of high purity (>99\%) and tetrabutylphosphonium chloride, $\left[\mathrm{P}_{4,4,4,4}\right] \mathrm{Cl}(>95 \%)$, were purchased from IoLiTec (Heilbronn, Germany). The inorganic acids were puriss. p.a., $\mathrm{H}_{2} \mathrm{SO}_{4}$ was supplied by Sigma-Aldrich, $\mathrm{HCl}$ was a domestic product (Bulgaria). The substances required for the analyses, phenol, DNS, Folin-Ciocalteu's reagent, Rochelle salt, $\mathrm{Na}_{2} \mathrm{CO}_{3}, \mathrm{NaOH}$ were all of analytical grade.

The Enteromorpha linza alga was harvested on 27th of June 2017 from a rocky shore at the Elenite, Bulgaria (lat. of $42^{\circ} 42^{\prime} 3.66^{\prime \prime} \mathrm{N}$; long. of $27^{\circ} 48^{\prime} 28.43^{\prime \prime} \mathrm{E}$ ). It was rinsed with tap water, dried to the air and sun, and grinded until the particles passed through a 70 mesh sieve.

The powdered alga was subjected to solid-liquid extraction-hydrolysis in a laboratory autoclave at $121{ }^{\circ} \mathrm{C}$ for $40 \mathrm{~min}$. The process was carried out at solid-toliquid ratio of 1:25 (w/v). The liquid phase was distilled water or an aqueous solution of the catalyst, $0.06 \mathrm{~mol} \mathrm{dm}^{-3}$ of the acid or the IL.

After autoclaving the solid phase was sunk by centrifugation at $10000 \mathrm{rpm}$ for 15 min. The liquid phase was subjected to quantitative analyses for total carbohydrates (Dubois et al 1956), reducing sugars (Miller 1959), monosaccharides by HPLC equipped with a RI detector (LC-25 Perkin Elmer) and Aminex HPX-87H column (mobile phase $0.005 \mathrm{M} \mathrm{H}_{2} \mathrm{SO}_{4}$ at a flow rate of $0.6 \mathrm{ml} / \mathrm{min}, 65{ }^{\circ} \mathrm{C}$ ), total protein (Lowry et al 1951) and total phenolics (Waterhouse 2001).

The initial carbohydrate content of the dried Enteromorpha linza alga was also assayed following the phenol-sulfuric acid protocol (Dubois et al 1956) and was determined to be $23.4 \%$ (w/w).

\section{Results and Discussion}

Two ILs were selected to be studied and compared with the inorganic acids used in extraction and hydrolysis of algal polysaccharides. The one was [ $\left.\mathrm{C}_{4} \mathrm{C}_{1} \mathrm{im}\right] \mathrm{Ac}$ which is exploited in lignocellulose pre-treatment, as it was discussed above. The other was $\left[\mathrm{P}_{4,4,4,4}\right] \mathrm{Cl}$, a cheap IL which was chosen because of the acidic $\mathrm{pH}$ of its aqueous solution at the given concentration $(\mathrm{pH}=2.09)$. The aqueous solution of $\left[\mathrm{C}_{4} \mathrm{C}_{1} \mathrm{im}\right] \mathrm{Ac}$ at the same concentration has $\mathrm{pH}=5.56$. These ILs solutions were compared to the aqueous solutions of $\mathrm{HCl}(\mathrm{pH}=1.20)$ and $\mathrm{H}_{2} \mathrm{SO}_{4}(\mathrm{pH}=1.13)$ with respect to the effect on the extraction extent and the efficiency of hydrolysis of the polysaccharide derived from the autoclaved Enteromorpha linza alga. 


\section{INTERNATIONAL SYMPOSIUM "THE ENVIRONMENT AND THE INDUSTRY", SIMI 2018, PROCEEDINGS BOOK}

\section{Carbohydrate extraction}

Enteromorpha linza alga contains ulvan as the main polysaccharide, which is a sulphated rhamnoglucuronan (Rioux \& Turgeon 2015). The total carbohydrate content of the extracts is the primary indication for the polysaccharide recovery. Figure 1 represents the percentage amount of the extracted carbohydrates regarding the total carbohydrate content of the dried alga $(23.4 \% \mathrm{w} / \mathrm{w})$. First of all, the

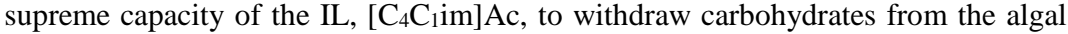
matrix should be highlighted. The highest extraction degree of total carbohydrates $(\mathrm{TCH}), 99.3 \%$, was attained in the case of $\left[\mathrm{C}_{4} \mathrm{C}_{1} \mathrm{im}\right] \mathrm{Ac}-$ treated alga.

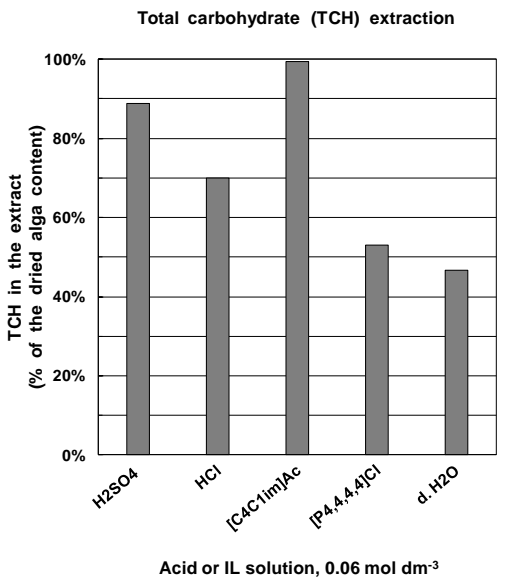

Figure 1. Effect of the acid or IL added on the extraction of algal carbohydrates

Lower contents of TCH were yielded in the liquor by treating the alga with acids solutions, even when the dibasic $\mathrm{H}_{2} \mathrm{SO}_{4}$ was used. The $\mathrm{TCH}$ extraction in the presence of $\mathrm{HCl}$ was substantially less effective (70.1\%) and only the half of the algal carbohydrate content was extracted in the case of the IL, $\left[\mathrm{P}_{4,4,4,4}\right] \mathrm{Cl}$, similarly to the reference case of distilled water. Despite the acidic $\mathrm{pH}$ of the aqueous solution of $\left[\mathrm{P}_{4,4,4,4}\right] \mathrm{Cl}$, the extraction was not positively affected.

\section{Carbohydrate hydrolysis}

Reducing sugar and monosugar contents

Further, the degree of polysaccharide hydrothermal hydrolysis in the presence of acids and ILs was evaluated by measuring the fraction of reducing sugar content. Results are displayed in Figure 2A. As it was expected, the dibasic acid, $\mathrm{H}_{2} \mathrm{SO}_{4}$ which is a donor of two reactive protons, exerted the most powerful hydrolytic action on the polysaccharide chain. $81.1 \%$ of the extracted carbohydrates responded to the analysis for reducing sugars. A smaller fraction of reducing sugars, $29.5 \%$, was obtained by using the monobasic acid catalyst, $\mathrm{HCl}$. Based on the total carbohydrate content of the dry alga, the fraction of reducing sugars yielded in the extract with the aid of $\left[\mathrm{C}_{4} \mathrm{C}_{1} \mathrm{im}\right] \mathrm{Ac}$ was $c a$. $20 \%$, which was comparable to that one hydrolyzed by $\mathrm{HCl}$ catalyst. This reveals the potential of the IL, [ $\left.\mathrm{C}_{4} \mathrm{C}_{1} \mathrm{im}\right] \mathrm{Ac}$, to play 


\section{INTERNATIONAL SYMPOSIUM "THE ENVIRONMENT AND THE INDUSTRY", SIMI 2018, PROCEEDINGS BOOK}

a double function as an extractant for the polysaccharide and a catalyst for its hydrolysis.

The share of the monosugars in the whole reducing sugar content was estimated based on the HPLC analysis. Two peaks appeared on the chromatogram and they were attributed to glucose and rhamnose monosugars. The sum of their concentrations was used to calculate the monosugar fraction. Results are presented in Figure 2B. More than the half of the reducing sugar content released by $\mathrm{H}_{2} \mathrm{SO}_{4}$ was estimated to be the fraction of monosugars. Interestingly, the hydrolysis by [ $\mathrm{C}_{4} \mathrm{C}_{1}$ im] Ac also gave a substantial monosugar fraction which was even higher than

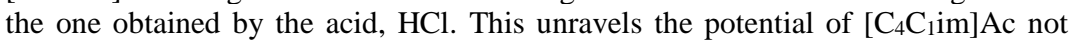
only to extract, but also to hydrolyze the algal carbohydrates directly to simple sugars. The yield in the case of $\left[\mathrm{C}_{4} \mathrm{C}_{1}\right.$ im] Ac exceeded the maximal yield of reducing sugars reported for Enteromorpha intestinalis alga (14.3\% on the basis of TCH) obtained under much more severe hydrothermal conditions which require a temperature of $170{ }^{\circ} \mathrm{C}$ and a pressure of $7.94 \mathrm{bar}$ (Kim et al. 2014). Here, with much less energy input the algal polysaccharide was totally extracted and partially converted to simple sugars. The hydrolysis could be accomplished either through optimization of the IL's concentration or by post-hydrothermal enzymatic hydrolysis. As a whole, the treatment by $\mathrm{H}_{2} \mathrm{SO}_{4}$ resulted in the greatest production of reducing and monosugars, but it was shown to be associated with the increase in the formation of dehydration by-products, such as 5-HMF and levulinic acid (Meinita et al 2012). These by-products, however, are known to inhibit both the post-hydrothermal enzymatic hydrolysis (Kim et al 2014) and the microbial growth and production (Larsson et al 1999).

\section{Protein content}

Besides the polysaccharides, the crude protein derived from macroalgae can additionally enhance the nutritional value of the algal liquor. Proteins that occur in the plant material are usually combined with polyphenolics in complexes. Quantitation of protein has proved to be difficult because the majority of standard methods ( $\mathrm{A}_{280}$, Lowry assay, Bradford assay, bicinchoninic acid assay) are susceptible to the functional phenolic groups both present in the polyphenols and in the aromatic amino acids of the proteins (Hagerman 2012). 
(A) - Reducing sugar (RS) fraction

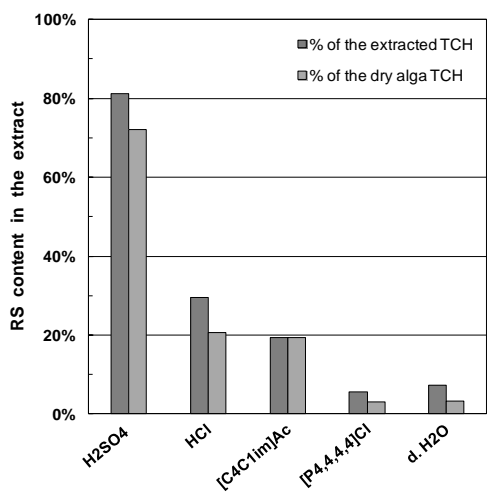

Acid or IL solution, $0.06 \mathrm{~mol} \mathrm{dm}^{-3}$
(B) - Monosugar (MS) fraction

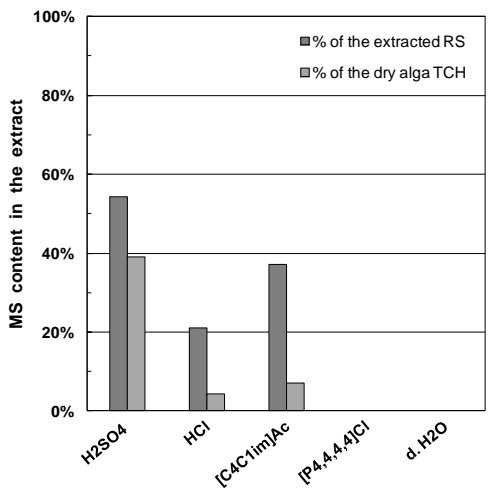

Acid or IL solution, $0.06 \mathrm{~mol} \mathrm{dm}^{-3}$

Figure 2 (A-B). Effect of the added acid or ILon the hydrolysis of the polysaccharide. (A) - reducing sugar fraction; (B) - monosugar fraction

First the extracts from Enteromorpha linza alga were assayed for the presence of polyphenols (Waterhouse 2001, Singleton et al 1999). Minor polyphenol amounts were detected. The concentration of the $\mathrm{H}_{2} \mathrm{SO}_{4}-$ extract was $0.128 \mathrm{~g} \mathrm{dm}^{-3}$, while in all the others it was $\leq 0.071 \mathrm{~g} \mathrm{dm}^{-3}$. The low polyphenolics content gave us the opportunity to obtain some rough results about the protein content by using Lowry method which was shown to be more suitable for a similar case (Redmile-Gordon et al 2013). The protein concentrations of the algal extracts are shown in Figure 3.

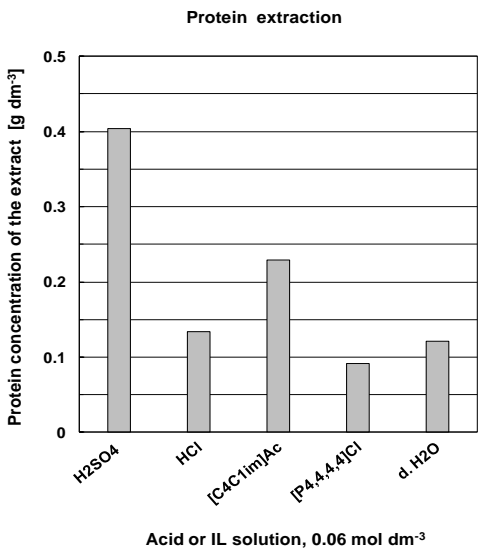

Figure 3. Effect of the acid or IL added on the extraction of proteins 


\section{INTERNATIONAL SYMPOSIUM "THE ENVIRONMENT AND THE INDUSTRY", SIMI 2018, PROCEEDINGS BOOK}

Expectedly, the combination of a strong acid $\left(\mathrm{H}_{2} \mathrm{SO}_{4}\right)$ and a high temperature (during the autoclaving) caused a severe destruction of the algal tissue that resulted in biopolymers' release. Although the concentration of the total protein extracted was low, it can be seen that the $\mathrm{IL},\left[\mathrm{C}_{4} \mathrm{C}_{1} \mathrm{im}\right] \mathrm{Ac}$, has the potential to withdraw the proteins from the material. The amount extracted by this IL was almost double compared to the water extraction and significantly greater than by the acid, $\mathrm{HCl}$. As it was already discussed, the Ac-anion is able to break any kind of $\mathrm{H}$-bonds down, including those of protein carboxyl groups, thus probably making the protein extraction easier (Dang et al 2018).

\section{Conclusions}

The experimental results showed the supremacy of the IL, $\left[\mathrm{C}_{4} \mathrm{C}_{1} \mathrm{im}\right] \mathrm{Ac}$, over the both acid auxiliaries $\left(\mathrm{H}_{2} \mathrm{SO}_{4}\right.$ and $\left.\mathrm{HCl}\right)$ in algal carbohydrate extraction. 99.3\% of the total carbohydrate content of the Enteromorpha linza alga was recovered in the liquor. The capacity of $\left[\mathrm{C}_{4} \mathrm{C}_{1} \mathrm{im}\right] \mathrm{Ac}$ for splitting reducing sugars under the conditions of hydrothermal hydrolysis is comparable with those of $\mathrm{HCl}$, but superior to $\mathrm{HCl}$ in terms of monosugar release and protein yield. As it was expected, the highest concentrations of reducing and monosugars were obtained by using the strong dibasic acid, $\mathrm{H}_{2} \mathrm{SO}_{4}$. However, the formation of dehydration by-products, such as 5-HMF and acids, in addition to the low $\mathrm{pH}(=1.43)$, would inhibit the next biological processes, the enzymatic hydrolysis to fulfill the monosugar composition or the microbial production fed by the algal liquor. Contrary, the extract derived from the alga pretreated by $\left[\mathrm{C}_{4} \mathrm{C}_{1}\right.$ im $]$ Ac has a neutral $\mathrm{pH}(=6.58)$ thus providing a favorable condition for microbial processes. Moreover, the content of the total protein released additionally increases the nutritional value of the must. These first

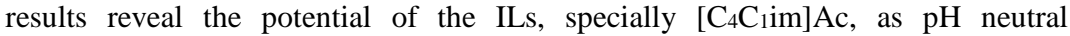
extractants and catalysts for valorization of macroalgae as renewable sources for microbial and chemical production. Future studies will be carried to investigate the ILs effects on the selectivity of extraction from algal material and on its posthydrothermal enzymatic hydrolysis.

\section{Acknowledgement}

The authors thank Prof. Dr. Daniela Dzhonova-Atanasova heartily for providing the Enteromorpha linza alga.

\section{References}

Bogdanov, MG \& Svinyarov, I 2013, 'Ionic liquid-supported solid-liquid extraction of bioactive alkaloids. II. Kinetics, modelling and mechanism of glaucine extraction from Glaucium flavum Cr. (Papaveraceae)', Separation and Purification Technology, vol. 103, pp. 279-288.

Dang, TT, Bowyer, MC, Van Altena, IA \& Scarlett, CJ 2018, 'Optimum conditions of microwave-assisted extraction for phenolic compounds and antioxidant capacity of the brown alga Sargassum vestitum', Separation Science and Technologies, vol. 53, no.11, pp. 1711-1723.

Dong, K \& Zhang, S 2012, 'Hydrogen bonds: A structural insight into ionic liquids', Chemistry A European Journal, vol.18, no.10, pp. 2748-2761. 


\section{INTERNATIONAL SYMPOSIUM "THE ENVIRONMENT AND THE INDUSTRY", SIMI 2018, PROCEEDINGS BOOK}

Dubois, M, Gilles, KA, Hamilton, JK, Rebers, PA \& Smith, F 1956, 'Colorimetric method for determination of sugars and related substances', Analytical Chemistry, vol.28, pp. 350-356.

Freire, MG, Neves, CMSS, Marrucho, IM, Coutinho, JAP \& Fernandes, AM 2010, 'Hydrolysis of tetrafluoroborate and hexafluorophosphate counter ions in imidazolium-based ionic liquids', Journal of Physical Chemistry A, vol.114, pp. 3744-3749.

Guiry, MD 2018, In: Guiry M.D., Guiry G.M. (eds.), AlgaeBase. World-wide electronic publication, National University of Ireland, Galway. Available from: http://www.algaebase.org. [21 May 2018].

Hagerman, AE 2012, 'Chapter 3 - Fifty years of polyphenol-protein complexes', in Cheynier V., Sarni-Manchado P., Quideau S. (eds.), Recent Advances in Polyphenol Research, vol. 3, 1st edition, John Wiley \& Sons, Ltd., UK.

Husson, E, Auxenfans, T, Herbaut, M, Baralle, M, Lambertyn, V, Rakotoarivonina, H, Rémond, C \& Sarazin, C 2018, 'Sequential and simultaneous strategies for biorefining of wheat straw using room temperature ionic liquids, xylanases and cellulases', Bioresource Technology, vol. 251, pp. 280-287.

Kim, D-H, Lee, S-B \& Jeong, G-T 2014, 'Production of reducing sugar from Enteromorpha intestinalis by hydrothermal and enzymatic hydrolysis', Bioresource Technology, vol. 161, pp. 348-353.

Larsson, S, Palmqvist, E, Hägerdal, BH, Tengborg, C, Stenberg, K, Zacchi, G \& Nilvebrant, N-O 1999, 'The generation of fermentation inhibitors during dilute acid hydrolysis of softwood', Enzyme and Microbial Technology, vol. 24, no.3-4, pp. 151-159.

Lowry, OH, Rosebrough, NJ, Farr, AL \& Randall, RJ 1951, 'Protein measurement with the Folin Phenol reagent', Journal of Biological Chemistry, vol.193, no.1, pp. 265-275.

Meinita, MDN, Hong, Y-K \& Jeong, G-T 2012, 'Comparison of sulfuric and hydrochloric acids as catalysts in hydrolysis of Kappaphycus alvarezii (cottonii)', Bioprocess and Biosystems Engineering, vol. 35, pp. 123-128.

Miller, GL 1959, 'Use of dinitrosalicylic acid reagent for determination of reducing sugar’, Analytical Chemistry, vol. 31, no. 3, pp. 426-428.

Park, D-H \& Jeong, G-T 2013, 'Production of reducing sugar from macroalgae Saccharina japonica using ionic liquid catalyst', Korean Chemical Engineering Research, vol. 51, no.1, pp. 106-110.

Raj, T, Gaur, R, Lamba, BY, Singh, N, Gupta, RP, Kumar, R, Puri, SK \& Ramakumar, SSV 2018, 'Characterization of ionic liquid pretreated plant cell wall for improved enzymatic digestibility’, Bioresource Technology, vol. 249, pp. 139-145.

Redmile-Gordon, MA, Armenise, E, White, RP, Hirsch, PR \& Goulding, KWT 2013, 'A comparison of two colorimetric assays, based upon Lowry and Bradford techniques, to estimate total protein in soil extracts', Soil Biology and Biochemistry, vol. 67, pp. 166-173.

Rioux, L-E \& Turgeon, SL 2015, 'Chapter 7 - Seaweed carbohydrates', in Tiwari BK, Troy DJ eds., Seaweed Sustainability. Food and Non-Food Applications, Academic Press, Elsevier Inc., pp. 141-192.

Robic, A, Rondeau-Mouro, C, Sassi, JF, Lerat, Y \& Lahaye, M 2009, 'Structure and interactions of ulvan in the cell wall of the marine green algae Ulva rotundata 


\section{INTERNATIONAL SYMPOSIUM "THE ENVIRONMENT AND THE INDUSTRY", SIMI 2018, PROCEEDINGS BOOK}

(Ulvales Chlorophyceae)', Carbohydrate Polymers, vol. 77, no.2, pp. 206216.

Robin, A, Chavel, P, Chemodanov, A, Israel, A \& Golberg, A 2018 a, 'Corrigendum to "Diversity of monosaccharides in marine macroalgae from the Eastern Mediterranean Sea”', Algal Research, vol. 32, pp. 384.

Robin, A, Chavel, P, Chemodanov, A, Israel, A \& Golberg, A 2018b, 'Diversity of monosaccharides in marine macroalgae from the Eastern Mediterranean Sea', Algal Research, vol. 28, pp. 118-127.

Singleton, VL, Orthofer, R \& Lamuela-Raventos, RM 1999, 'Analysis of total phenols and other oxidation substrates and antioxidants by means of FolinCiocalteu reagent', Methods in Enzymology, vol. 299, pp. 152-178.

Waterhouse, AL 2001, 'Determination of total phenolics', in Wrolstad RE ed., Current Protocols Food Analytical Chemistry, John Wiley, NY, vol.6, pp. 11.11-11.18.

Yaich, H, Garna, H, Besbes, S, Barthélemy, J-P, Paquot, M, Blecker, C \& Attia, H 2014, 'Impact of extraction procedures on the chemical, rheological and textural properties of ulvan from Ulva lactuca of Tunisia coast', Food Hydrocolloids, vol. 40, pp. 53-63. 